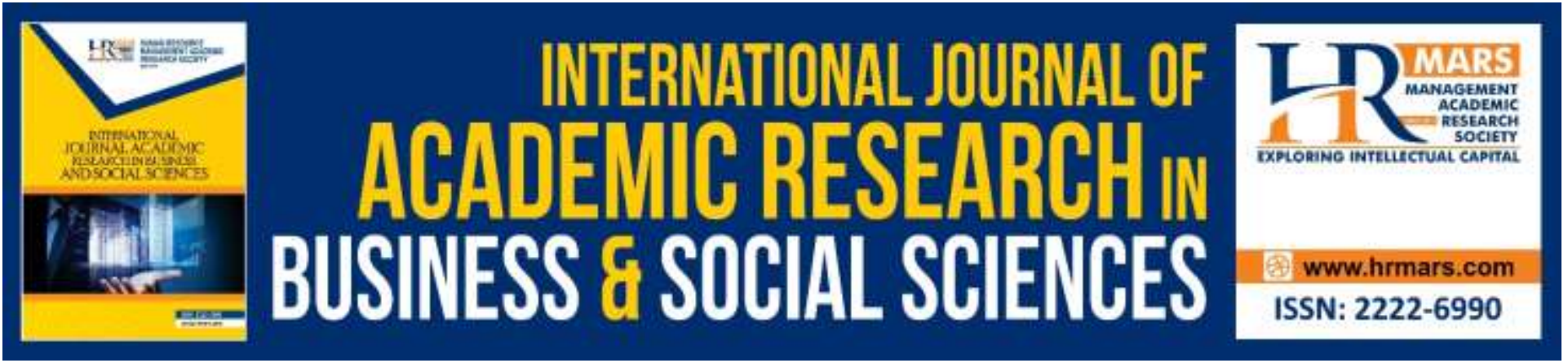

\title{
Demanded Competencies of the Entry-Level Position in the Restaurant Industry: Employers' Perspectives
}

Siti Fatimah Mohamad, Lee Lik Ying, Mohiddin Othman, Ungku Fatimah Ungku Zainal Abidin, Farah Adibah Che Ishak, Ainul Zakiah Abu Bakar

To Link this Article: http://dx.doi.org/10.6007/IJARBSS/v10-i3/7095

DOI:10.6007/IJARBSS/v10-i3/7095

Received: 06 February 2020, Revised: 20 February 2020, Accepted: 12 March 2020

Published Online: 31 March 2020

In-Text Citation: (Mohamad et al., 2020)

To Cite this Article: Mohamad, S. F., Ying, L. L., Othman, M., Abidin, U. F. U. Z., Ishak, F. A. C., \& Bakar, A. Z. A. (2020). Demanded Competencies of the Entry-Level Position in the Restaurant Industry: Employers' Perspectives. International Journal of Academic Research in Business and Social Sciences, 10(3), 823-835.

Copyright: (C) 2020 The Author(s)

Published by Human Resource Management Academic Research Society (www.hrmars.com)

This article is published under the Creative Commons Attribution (CC BY 4.0) license. Anyone may reproduce, distribute, translate and create derivative works of this article (for both commercial and non-commercial purposes), subject to full attribution to the original publication and authors. The full terms of this license may be seen at: http://creativecommons.org/licences/by/4.0/legalcode

Vol. 10, No. 3, 2020, Pg. 823 - 835

http://hrmars.com/index.php/pages/detail/IJARBSS

JOURNAL HOMEPAGE

Full Terms \& Conditions of access and use can be found at http://hrmars.com/index.php/pages/detail/publication-ethics 


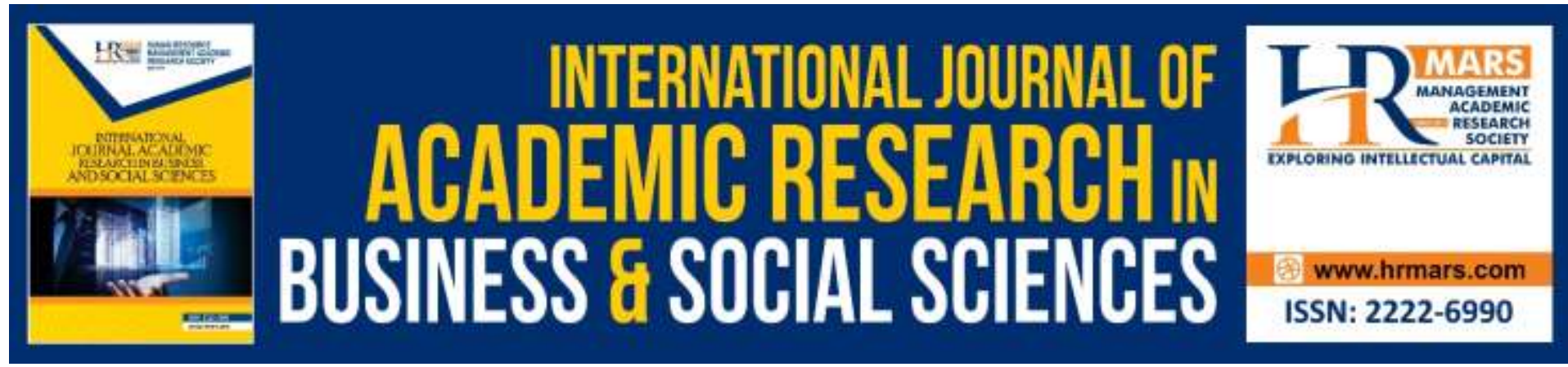

\title{
Demanded Competencies of the Entry-Level Position in the Restaurant Industry: Employers' Perspectives
}

\author{
Siti Fatimah Mohamad, Lee Lik Ying, Mohiddin Othman, Ungku \\ Fatimah Ungku Zainal Abidin and Farah Adibah Che Ishak, Ainul \\ Zakiah Abu Bakar \\ Department of Food Service and Management, Faculty of Food Science and Technology, UPM \\ Serdang, 43400 Serdang, Selangor, Malaysia. \\ Email: s_fatimah@upm.edu.my
}

\begin{abstract}
Researchers advocated that there are many issues of fresh graduates' competencies, including insufficient skills to meet the requirement as expected by the industry. The purpose of this study was to discover the entry-level competencies demanded by the restaurant employers towards fresh graduates. The dynamic workforce and the mismatch competencies claimed by employers are the issues that trigger education stakeholders, particularly in Malaysia. Responses were obtained from eight restaurant managers in Klang Valley, through a semi-structured interview. The data were then analyzed using thematic analysis. There were nine competencies emerged from this study, which reflect the entry-level competencies demanded by restaurant managers towards fresh graduates, namely: 1) attitude and behavior, 2) cognitive skill, 3) communication skill, 4) knowledge in the discipline area, 5) professionalism and work ethics, 6) technical skill, 7) teamwork, 8) leadership and 9) experience. It is anticipated that the findings will be able to fulfill the restaurant's needs by giving a clear picture of the essential competencies that need to be infused in the university's curriculum. Besides, both educators and fresh graduates will have an insight into the preparation for working in the restaurant industry.
\end{abstract}

Keywords: Competencies, Entry-Level, Fresh Graduates, Restaurant Industry, Employers' Perspective

\section{Introduction}

The Department of Statistics Malaysia (2018) proclaimed that by August 2018, the labor force in Malaysia is approximately 15 million, and the highest unemployment rate was $3.4 \%$. According to the study, the current unemployment rate of $3.4 \%$ was generally accepted as the international labor organization (ILO), stating that any country with an unemployment rate that not more than $4 \%$ is considered as full employment. Nevertheless, the unpleasant news behind the statistics showed that the youth unemployment rate, $13.2 \%$ was over three times higher than the national average, $3.4 \%$. The common reasons that contribute to the high youth unemployment rate were because of the lack of job experiences and insufficient competencies amongst the millennials (Singh and Singh 2008). Rahmah, Ishak and Lai (2011) also advocated that the quality of fresh graduates is one of the critical factors that contribute to the Malaysian graduates' unemployment problem. 
It has been reported that university students have lacked soft skills, especially problem-solving and communication skills, while for the hard skills, they were lack of technical knowledge, difficulty in applying knowledge, and lack of English communication skills (Hanapi and Nordin, 2014; Lim et al. 2016). There were some fundamental weaknesses of fresh graduates in the management orientation, including problem-solving, communication, leadership, creativity, critical thinking, proactive, selfconfidence, and interaction skill. The fresh graduates who lacked these skills had difficulties in meeting the company's qualifications and getting jobs (Hanapi and Nordin, 2014). Singh and Singh (2008) and Seetha (2014) declared that the lack of competencies results in the mismatch between the competencies supply and demand. The latest Graduates Tracer Study reported that there were over 57,000 of unemployed graduates in 2018 (Ministry of Higher Education 2019). Some would claim that it is the responsibility of higher education institutions to educate and equip fresh graduates with the required knowledge and skills, to ensure that they are well-equipped with the competencies demanded by the industry (Abd Majid et al. 2018).

The issues of graduate competencies were also identified within the hospitality industry. The growth of this industry, including the restaurant sector, has resulted in the increased demand for the competent employee (Sisson and Adams 2013). However, the hospitality employers discovered that fresh graduates did not possess suitable competencies and qualifications according to the requirements expected by employers (Cheung et al. 2010; Ismail et al. 2011; Hsu 2012). As the hospitality industry has significantly shifted from a skill-based sector to a knowledge-based industry, the higher education institutions play a vital role in exploiting the students' career path and assisting the hospitality managers to be more fully coordinate with the culture, services and competitive aspects of the sector (Abd Majid et al. 2018). Sewell and Dacre (2010) also agreed that higher education institutions are highly responsible for supplying potential employees or entrepreneurs into the competitive labor market. Hence, there is no doubt that the educational institutions have a strong correlation with the hospitality industry to provide the fresh graduates who are well-equipped in competencies demanded by the industry.

According to Chia and Chu (2016), Malaysian fresh graduates who are at the age of 20s could not confront the work pressure, yet they were expecting on the job with a high paid salary, in which they would prefer to straight get in the upper position instead of gain experience from the entry-level position. The mentality of demand position with fat salary had been slowly ingrained amongst fresh graduates. Tesone and Ricci (2005) revealed that hospitality managers preferred fresh graduates with the right attitude. The attitudes were comprising optimism, achievement, and pride in assisting others. Besides, the study also commented that it would be better if graduates have good teamwork, empathy, the anticipation of customer needs as well as patience for vagueness while they work in the industry. Though there were studies that indicated competencies required by the hospitality industry, the findings were lack of elaboration on what are the components for each competency, particularly within the restaurant industry in Malaysia. Thus, this study aimed to discover the demanded entrylevel job competencies perceived by the restaurant employers, where the entry-level job reflecting the fresh graduate's position.

\section{Literature Review}

This chapter comprises the literature review of types of competencies and competencies lacking among fresh graduates. 


\section{Types of Competencies}

The industry has been changing dramatically because of globalization, advancement in technology, and changes in the economic landscape, thus leading to the required competencies identification in the hospitality industry became important (Weber et al. 2009). According to Singh and Pathak (2016), competencies can be grouped into five categories, which were managerial competency, functional competency, core competency, career stream competency, and technical or professional competency. On the other hand, Sanghi (2016) described that competency could also be distinguished into two natures, including threshold competencies and differentiating competencies. He mentioned that threshold competencies were the elementary characteristics that employees should have in order to be minimally effective, without differentiating the superior from average performers. While differentiating competencies are the factors that discern outstanding from average performers.

According to Allen et al. (2005), competencies can be categorized into specific competencies and generic competencies. Specific competencies were the clusters of prior cognitive conditions that a person should possess to be able to perform sufficiently in a given extensive territory (Weinert 2001). They usually referred to the profession or field-specific skills and knowledge associated with the work tasks in the work environment. For the generic competencies, they were the skills or techniques such as the ability to learn (conceptual competency), communication, and teamwork skills that ought to be harness for better achievement in the work environment (Thompson et al. 1997).

\section{Competencies Lacking among Fresh Graduates}

There were too many fresh graduates leaves their universities without acquiring the knowledge they have learned as they neglected the importance of the skills and attitudes, which are the prerequisite for entering the work environment. Besides, fresh graduates were perceived to be incompetent when they entered the workforce and did not understand the competencies demanded by the industry (Brenda, 2003). Across the different settings, many researchers (Cheung et al. 2010; Sisson and Adams, 2013; Tesone and Ricci, 2005; Tsai et al. 2006; Zaitseva et al. 2017) summarized that the competencies of teamwork, communication, interpersonal skills, creativity, leadership, as well as technical skills, were the most critical of competencies lacking from fresh graduates, particularly within the hospitality industry over the years. Wang and Tsai (2014) stated that due to the concern of whether students could meet the requirement of the industry, the reality of the hospitality workforce should be communicated through the hospitality curriculum. For instance, providing opportunities to fresh graduates to interact more with others to enhance their soft skills, train them to be well-educated and knowledgeable regarding the foodservice industry, and cultivate their competencies in order to escalate graduates' employability in the hospitality industry.

\section{Methodology}

This study employed a qualitative research design as it is a naturalistic approach that casts on the phenomena in a context-specific setting (Patton 2002). Besides, this study used purposive sampling, in which it refers to the intentional selection of respondents due to the qualities they possess (Tongco 2007). The target population of this study included the restaurants in Klang Valley. Klang Valley, also known as Greater Kuala Lumpur, is an area in Malaysia located in central Selangor, where it mainly comprises Kuala Lumpur, Putrajaya, and the adjacent cities and towns in the state of Selangor. This study obtained approval from the Ethics Committee for Research Involving Human Subjects from Universiti Putra Malaysia. Semi-structured questions were asked through a face-to-face interview with 
respondents who met the required criteria: 1) managerial level in Klang Valley restaurants, 2) involve in the recruitment process of hiring fresh graduates, and 3) engage in the fresh graduate's training. A total of eight respondents were selected as the respondents for this study, where data saturation reached at the eighth respondent. The saturation of data refers to the point where the researcher stops collecting data as there are no longer new insights revealed for the categories or themes emerged (Charmaz 2006). During the interview, the information on the demanded entry-level job competencies was collected by taking notes manually and audio recording for transcription into a transcript. Then, the data were analyzed by the aid of Atlas.ti software through analytical coding, where the text was coded accordingly and categorized into different themes. The validity and reliability of the codes and themes were performed through the expert review which involved professionals in the related field. Besides, an inter-rater agreement was conducted to achieve consensus among three raters for the development of the competency themes.

\section{Results and Discussion}

\section{Respondents' Demographics}

There was a total of eight respondents participated in this study. Seven respondents were male, and there was only one female respondent in this study. The majority of the respondents were Malay. Half of the respondents were in the position of Restaurant Manager, followed by the rest who were Restaurant General Manager, Kitchen Restaurant, Assistance Restaurant Manager, and Supervisor.

As for the information on the length of service, it is broken into two categories: 1 ) in the current position, and 2) in the hospitality industry. The length of service for the current position, two respondents worked for less than two years, and another two respondents worked between one to three years. One respondent had worked in his current position for seven years. On the other hand, the majority of the respondents worked in the hospitality industry for less than 10 years, and another three respondents worked in between 15 to 18 years in the hospitality industry.

Based on the date revealed from Table 1, all informants reported that they offered entry-level job position to fresh graduates. The entry-level job can be categorised into two types which are managerial position like supervisor and assistant restaurant manager and non-managerial position such as server. The majority of the respondents commented that the restaurant provided managerial position for entry-level job, including management trainee or Manager-In-Training (MIT), supervisor and assistant restaurant manager. 
INTERNATIONAL JOURNAL OF ACADEMIC RESEARCH IN BUSINESS AND SOCIAL SCIENCES

Vol. 10, No. 3, March, 2020, E-ISSN: 2222-6990 @ 2020 HRMARS

Table 1: Demographic information of the respondents

\begin{tabular}{|c|c|c|c|c|c|}
\hline Code & $\begin{array}{l}\text { Race/ } \\
\text { Gender* }\end{array}$ & Position & $\begin{array}{l}\text { Length of } \\
\text { service for the } \\
\text { current } \\
\text { position }\end{array}$ & $\begin{array}{l}\text { Length of } \\
\text { service in the } \\
\text { hospitality } \\
\text { industry }\end{array}$ & $\begin{array}{l}\text { Entry-level job } \\
\text { offered to fresh } \\
\text { graduates }\end{array}$ \\
\hline R01 & Malay/M & Restaurant Manager & 3 years & 15 years & $\begin{array}{l}\text { Non-managerial } \\
\text { level }\end{array}$ \\
\hline R02 & Indian/M & $\begin{array}{ll}\text { Restaurant } & \text { General } \\
\text { Manager } & \\
\end{array}$ & 7 years & 18 years & Managerial level \\
\hline R03 & Malay/F & Supervisor & $\begin{array}{l}1 \text { year } 5 \\
\text { months }\end{array}$ & $\begin{array}{l}1 \text { year } 5 \\
\text { months }\end{array}$ & Managerial level \\
\hline R04 & Malay/M & Restaurant Manager & 1 year & 7 years & Managerial level \\
\hline R05 & Malay/M & Restaurant Manager & 3 months & 17 years & Managerial level \\
\hline R06 & $\begin{array}{l}\text { Sabahan/ } \\
\text { M }\end{array}$ & Restaurant Manager & 2 years & 4 years & Managerial level \\
\hline R07 & Malay/M & $\begin{array}{ll}\text { Assistant } & \text { Restaurant } \\
\text { Manager } & \\
\end{array}$ & 4 months & 4 years & Managerial level \\
\hline R08 & Malay/M & Kitchen Manager & 1 year & 8 years & Managerial level \\
\hline
\end{tabular}

*M $=$ Male, $\mathrm{F}=$ Female

\section{Demanded Entry-Level Competencies by the Restaurant Industry}

In response to the aim of this study, which to describe the essential entry-level job competencies as demanded by the restaurant employers, there were nine different competencies generated from this study, as presented in Table 2 below. The competencies comprise: 1) attitude and behavior, 2) cognitive skill, 3) communication skill, 4) knowledge in the discipline area, 5) professionalism and work ethics, 6) technical skill, 7) teamwork, 8) leadership and, 9) experience. 
INTERNATIONAL JOURNAL OF ACADEMIC RESEARCH IN BUSINESS AND SOCIAL SCIENCES Vol. 10, No. 3, March, 2020, E-ISSN: 2222-6990 @ 2020 HRMARS

Table 2: Demanded entry-level job competencies perceived by the restaurant employers

\begin{tabular}{|l|l|l|}
\hline No. & Competencies & Components of the competency \\
\hline 1 & Attitude and behaviour & $\begin{array}{l}\text { i) Affability, ii) Determination, iii) Endurance, } \\
\text { iv) Hardworking, v) Humble, vi) Open-minded, vii) } \\
\text { Patience, viii) Proactive, ix) Respect, x) Self-confidence, } \\
\text { xi) Self-motivated, xii) Trustworthy, xiii) Willingness to } \\
\text { learn }\end{array}$ \\
\hline 2 & Cognitive skill & $\begin{array}{l}\text { i) Creativity, ii) Fast learning, iii) Logical thinking, } \\
\text { iv) Problem-solving }\end{array}$ \\
\hline 3 & Communication skill & $\begin{array}{l}\text { i) } 360^{\circ} \quad \text { communication, ii) Compassionate } \\
\text { communication, iii) Confidence, iv) English } \\
\text { communication, } \\
\text { v) Explicit message }\end{array}$ \\
\hline 4 & $\begin{array}{l}\text { Knowledge in the discipline } \\
\text { area }\end{array}$ & $\begin{array}{l}\text { i) Auditing, ii) Culinary, iii) Food and beverage, iv) Food } \\
\text { safety, v) Human resource management, vi) ICT literacy, } \\
\text { vii) Nutrition, viii) Organization, ix) Process } \\
\text { management, } \\
\text { x) Sales and marketing }\end{array}$ \\
\hline 5 & $\begin{array}{l}\text { Professionalism and work } \\
\text { ethics }\end{array}$ & $\begin{array}{l}\text { i) Commitment to work, ii) Discipline, iii) Fairness, } \\
\text { iv) Grooming, v) Physical appearance, vi) Responsible }\end{array}$ \\
\hline 6 & Technical skill & $\begin{array}{l}\text { i) Customer service, ii) Equipment operation and control, } \\
\text { iii) Inventory management, iv) information technology, } \\
\text { v) Sales and marketing }\end{array}$ \\
\hline 7 & Teamwork & $\begin{array}{l}\text { i) Able to work with a diverse team, ii) Contribute to the } \\
\text { group, iii) Help each other }\end{array}$ \\
\hline 8 & Leadership & $\begin{array}{l}\text { i) Giving instruction, ii) Guiding people, iii) Monitoring, } \\
\text { iv) Motivating others, v) Planning }\end{array}$ \\
\hline 9 & Experience & $\begin{array}{l}\text { i) Better understanding of workplace realities, } \\
\text { ii) Work experience }\end{array}$ \\
\hline
\end{tabular}

There were 53 components that had been clustered into nine competencies. As each of the competencies has numerous components, each of the components will not be elaborated in this chapter. A summary of competencies' elaboration is presented as follow:

\section{Attitude and Behavior}

Attitude and behavior were reported to increase in magnitude that they correspond more closely in terms of their entities (Ajzen and Fishbein, 1977). There were 13 components emerged under the competency of attitude and behavior: i) affability, ii) determination, iii) endurance, iv) hardworking, v) humble, vi) open-minded, vii) patience, viii) proactive, ix) respect, $x$ ) self-confidence, xi) selfmotivated, xii) trustworthy, and xiii) willingness to learn. Affability was mentioned by the respondents as an essential component especially in the hospitality industry, as it is highly related to customer's enjoyable and pleasant. 
INTERNATIONAL JOURNAL OF ACADEMIC RESEARCH IN BUSINESS AND SOCIAL SCIENCES Vol. 10, No. 3, March, 2020, E-ISSN: 2222-6990 @ 2020 HRMARS

"Yes must have affability, must be nice... If simply follow SOP and taking orders without any feeling, customer will not feeling happy. He really has followed the SOP, but the way he delivers the service is not enough, customer cannot feel it." (code R06)

On the other hand, another respondent reported that the ability of endurance was critical in the workplace. Fresh graduates had to endure pressure from customers and superiors, as well as undergoing a high workload if they need to cover their colleagues. It is advisable for fresh graduates to have a strong endurance at the workplace. They would be facing different kinds of people every day with different personalities and behavior. These people include customers, superiors and their colleagues.

"They have to be able to endure pressure because you need to face customers. So, you need to have a strong mentality, like how to handle stress from boss... Sometimes we need to cover our colleagues' work, that's why we need to have strong endurance" (code R07)

\section{Cognitive Skill}

Cognitive skill is a measurement of human intellectual function that associated with effective performance over a broad range of academic and non-academic work (Perkins and Salomon 1989). The cognitive skill in this study comprises: i) creativity, ii) fast learning, iii) logical thinking, and iv) problem-solving. It is reported that fresh graduates had to be creative and innovative in helping the restaurant to solve problems, generate income and increase sales.

"Your plan, your idea, idea to improve sales. You must have creativity on how to improve sales. So, the most important for me is creativity. You are good to think, how to make sales, you are good to solve problem. let's say if you do the sales like this is not working, like this also won't work, so you have the plan B....at least you have it" (code R04)

The respondent described the characteristic of becoming fast-learner as the fresh graduates were expected to learn fast and be proficient in their tasks. Therefore, fresh graduates are required to have fast and precise learning process to produce outstanding performance in order to fulfill customers' satisfaction and their superiors.

"He needs to be fast-learner of course. For fast-learner, he learns fast, so can catch up everything, handle thing fast, easier to teach... When customer arrives but we don't serve him, he will complain, that's why we need to become fast-learner." (code R03)

\section{Communication Skill}

Communication skill is an ability to communicate in a form and manner which is clear, sensitive and appropriately varied in style and medium according to particular audiences and purposes (Boud and Solomon, 2001). Five components were grouped under this competency: i) $360^{\circ}$ communication, ii) compassionate communication, iii) confidence, iv) English communication, and v) explicit message. The respondent claimed that effective communication might attract customers to dine in at the restaurant, even if they were not getting interested at first to the product and food.

"How they talk to the customer to make sure the customer trust and support our product and dine in at our outlet. Because we do have the promotion, but the thing is how you talk to the customer, that makes customer very interested in you, very interested in your product... Because we want to 
INTERNATIONAL JOURNAL OF ACADEMIC RESEARCH IN BUSINESS AND SOCIAL SCIENCES Vol. 10, No. 3, March, 2020, E-ISSN: 2222-6990 @ 2020 HRMARS

increase our upselling product, so that's very important... We required people that can do promotion to attract customers, where these people must be able to communicate well." (code R03)

It was emphasized by the respondent that the way of delivering words should be straight to the point, when fresh graduates wanted to discuss or inform on serious matters. They should convey the message by stating it clearly and in detail, leaving no space for confusion or doubt to others.

"And then when you want to communicate, when you want to tell something serious, don't turn around, straight to the point." (code R01)

\section{Knowledge in the Discipline Area}

Scott and Yates (2002) defined the knowledge in the discipline area as a high level of current and relevant technical expertise, understanding of risk management and litigation, understanding of organizational operations, and integration of knowledge from many disciplines. Findings from this study revealed 10 dominant discipline areas that fresh graduates should have: i) auditing, ii) culinary, iii) food and beverage, iv) food safety, v) human resource management, vi) ICT literacy, vii) nutrition, viii) organization, ix) process management, and $\mathrm{x}$ ) sales and marketing. The respondents demanded fresh graduates to know audit to ease the work of an auditor. Each restaurant required a control system to ensure the standard and quality of the business operation. Therefore, fresh graduates must have knowledge in regards to auditing where they can be prepared when the auditing was performed.

"Knowledge also important because we have auditors. The auditors will check all SOP, cleanliness, SOP same with knowledge. So if you don't have the knowledge, it will mess up with the auditing and fail. So they need to have knowledge." (code R06)

Having sufficient culinary knowledge may contribute to the application of dietary recommendations, where the graduates may apply their knowledge in culinary to produce a healthy diet to the customers. The respondent perceived that it was essential for graduates to have the culinary knowledge even if they are assigned to work at the front of the house.

"... so if you have learned about cooking, that is good. At least when you get into the work you know kitchen. No need to know all, at least know a bit should be okay." (code R04)

\section{Professionalism and Work Ethics}

Professionalism or work ethics demonstrate personal accountability and effective work habits such as punctuality, working productively with others, time and workload management (Casner-Lotto and Barrington, 2006). The respondents of this study described professionalism and work ethics by having: i) commitment to work, ii) discipline, iii) fairness, iv) grooming, v) physical appearance, vi) responsible. It was reported that fresh graduates should give commitment to their work, and not giving excuse or always ask for leave. In addition, the respondent mentioned that graduates would want to learn more during working if they possess commitment to their work. Therefore, commitment to work is the key component as perceived by the respondent for continuous improvement in the restaurant industry. 
INTERNATIONAL JOURNAL OF ACADEMIC RESEARCH IN BUSINESS AND SOCIAL SCIENCES

Vol. 10, No. 3, March, 2020, E-ISSN: 2222-6990 @ 2020 HRMARS

"... like I mentioned earlier, if they have commitment want to work, they will be confirmed that they want to work, have willingness to know more about the food..." (code R07)

The respondent perceived that discipline encompasses the punctuality and work attendance of entrylevel employees. They also expected employees to be punctual by coming to work early and having a good discipline as it reflects professionalism.

"Discipline means attendance of working like that. Sometimes we as the students have class, we must have attendance class right? So same goes to work. Work, attendance, punctuality, attendance, discipline." (code R07)

\section{Technical skill}

Another entry-level competency demanded by the restaurant employers was the technical skill, involving: i) customer service, ii) equipment operation and control, iii) inventory management, iv) information technology, v) sales and marketing. According to Singh and Pathak (2016), technical skill refers to the specific ability to occupational areas, roles and jobs within the career stream competencies, including particular knowledge and skills to perform successfully. Findings from this study revealed that customer service skill was perceived as imperative in the restaurant industry, as the customer is the primary resource to generate income for the business.

"A customer just raised his hand; he wouldn't know whether the staff is new or experienced. A customer just wants somebody to come and take his order. So this is what we focus on, taking orders. After taking order we need to repeat the order to avoid mistakes in food production where later will lead to an argument with the customer." (code R03)

One of the respondents mentioned that fresh graduates should know about information technology. They should also acquire basic computer skills and key in data into the system. Hence, as the value of proficiency in using and managing information technology has increasingly demanded by the marketplace, fresh graduates ought to proficient in information technology.

"Hope they know about technology, IT all those things, IT technology. Because now we have the system, using the new system, so they must have the internet skill, computer skill, how to email, how to key in all stock." (code R07)

\section{Teamwork}

According to Knight and Yorke (2004), teamwork is defined as the ability to work constructively with others on a task. In this study, teamwork was perceived as essential skill in the restaurant industry and the respondents described the teamwork competency by: i) being able to work with a diverse team, ii) contribute to group, and iii) helping each other. The respondent underlined that fresh graduates should have the willingness to work with other people with different cultures even though it might be difficult. Teamwork is necessary for everyone in order to ensure the success of the team as a whole despite different backgrounds.

"Nowadays in Malaysia F\&B right, they must be willing to work with other cultures. We have, not only they work for Malaysian people, they should be willing to work with foreign people, where they come from different cultures. It is very hard." (code R02) 
INTERNATIONAL JOURNAL OF ACADEMIC RESEARCH IN BUSINESS AND SOCIAL SCIENCES

Vol. 10, No. 3, March, 2020, E-ISSN: 2222-6990 @ 2020 HRMARS

Besides, the restaurant employer requested the graduates to be more cooperative while working. They should be able to contribute to group in making the restaurant business a success.

"Yup need to have teamwork. Because when we have leadership, people will get to see our teamwork... If staying in a team, we need to exchange the ideas, so it can beautify the team." (code R01)

\section{Leadership}

Leadership refers to an ability to manage, motivate, monitor and support others. It is also related to providing vision and setting goals (Field 2001). The components of leadership skill in this study consisted of: i) giving instruction, ii) guiding people, iii) monitoring, iv) motivating others, and v) planning. The respondent mentioned that fresh graduates should know how to allocate tasks to their subordinates and assign them for the right position. Fresh graduates should have the leadership skill to guide people and provide clear instruction to their team.

"You guide them by taking out the staff schedule to check how many staff you have on that day. Then you must be able to give the instruction, and then you need to allocate section. Okay, A B C D $E$, so you must assign each of them, who will be the hostess, you need to assign and position them." (code R05)

The same respondent perceived that fresh graduates need to guide people by identifying and evaluate what are the weaknesses of their peers or subordinates, then assist them to improve their competencies and becoming proficient in their tasks. Guiding people is one of the key elements in the leadership competency demanded by the restaurant employers.

"... you have to know how to guide people... what are their weaknesses you must know, and then you need to guide from zero until becoming good." (code R05)

\section{Experience}

Experience had been highlighted by the respondents to better understand workplace realities and having work experience. The respondent stressed that the restaurant industry or even management department would value fresh graduates with work experience to join their organization. Those with hands-on experience, they might get a higher chance to be recruited by the employers:

"Basically, we see what your experience is... Maybe they don't have the hands-on. That's why I already tell you, experience is more important... At least 2 years experience working in an outlet. I think if you go to the management department, it is the same thing that management department will ask. Before you were sent there, they will see how much experience you have. Fresh graduate is the second option, mostly they will hire people with experience." (code R02)

\section{Conclusion}

This study has described nine entry-level job competencies perceived by the restaurant employers: 1) attitude and behavior, 2) cognitive skill, 3) communication skill, 4) knowledge in the discipline area, 5) professionalism and work ethics, 6) technical skill, 7) teamwork, 8) leadership and 9) experience. This study provides an insight on the key competencies of the entry-level job to the readers, especially for both fresh graduates and educators. It is anticipated to provide a clear picture to fresh graduates of the hospitality program on which main competencies to be equipped and infused for work 
INTERNATIONAL JOURNAL OF ACADEMIC RESEARCH IN BUSINESS AND SOCIAL SCIENCES

Vol. 10, No. 3, March, 2020, E-ISSN: 2222-6990 @ 2020 HRMARS

preparation in Malaysian restaurant industry. Subsequently, this study is beneficial to the higher education institutions particularly in Malaysia, where the educators can acquaint entirely what are the entry-level skillsets the hospitality industry desires for graduates. In conclusion, recognizing the needs for knowledge and skills of fresh graduates had resulted in the demand for the restaurant industry. Fresh graduates who acquire the designated competencies may have a competitive advantage compared to their friends and would be able to market themselves for employment. This will later help to increase the employment rate of hospitality graduates and add a quality talent pool for the hospitality industry.

\section{Acknowledgements}

This research was supported financially by the Universiti Putra Malaysia GP-IPM grant (Vote No. 9620300).

\section{References}

Abd Majid, A., Bujang, H., Rada, R., \& Eruthayam, L. (2018). Hospitality and Tourism Management. Retrieved April 10, 2019 from http://www.help.edu.my/pdf/hospitality/SHOT_2018.pdf.

Ajzen, I., \& Fishbein, M. (1977). Attitude-behavior Relations: A Theoretical Analysis and Review of Empirical Research. Psychological Bulletin, 84(5), 888-918.

Allen, J., Ramaekers, G., Van der Velden, R. (2005). Measuring Competencies of Higher Education Graduates, New Directions Institutional Research, No. 126, Wiley Periodicals, Inc.

Boud, D., \& Solomon, N. (2001). Work-based learning: A new higher education? England: SRHE \& Open University Press.

Brenda, L. (2003). The International Perspective on Employability. Center for Higher Education Research and Information and Generic Centre Colleague.

Casner-Lotto, J., \& Barrington, L. (2006). Are They Really Ready to Work? Employers' Perspectives on the Basic Knowledge and Applied Skills of New Entrants to the 21st Century U.S. workforce. USA: The Conference Board, Inc.

Charmaz, K. (2006). Constructing grounded theory: A practical guide through qualitative analysis. Thousand Oaks: SAGE Publication.

Cheung, C., Law, R., \& He, K. (2010). Essential Hotel Managerial Competencies for Graduate Students. Journal of Hospitality \& Tourism Education, 22(4), 25-32.

Chia, Y. M., \& Chu, M. J. (2016). Moderating Effects of Presenteeism on the Stress-happiness Relationship of Hotel Employees: A note. International Journal of Hospitality Management, 55, 52-56.

Field, L. (2002). Industry speaks! Skill requirements of leading Australian workplaces. Australia: DEST.

Hanapi, Z., \& Nordin, M. S. (2014). Unemployment Among Malaysia Graduates: Graduates' Attributes, Lecturers' Competency and Quality of Education. Procedia - Social and Behavioral Sciences, 112, $1056-1063$.

Hsu, Y. L. (2012). Role of Hospitality Management Department of Taiwan Universities in Addressing the Talent Needs of Taiwan's Hospitality Industry. African Journal of Business Management, 6(32), 9343-9358.

Husain, M. Y., Mokhtar, S. B., Ahmad, A. A., \& Mustapha, R. (2010). Importance of Employability Skills from Employers' Perspective. Procedia - Social and Behavioral Sciences, 7(2010), 430-438. 
INTERNATIONAL JOURNAL OF ACADEMIC RESEARCH IN BUSINESS AND SOCIAL SCIENCES

Vol. 10, No. 3, March, 2020, E-ISSN: 2222-6990 @ 2020 HRMARS

Ismail, R., Yussof, I., \& Sieng, L. W. (2011). Employers' Perceptions on Graduates in Malaysian Services Sector. International Business Management, 5(3), 184-193.

Knight, P., \& Yorke, M. (2004). Learning, curriculum and employability in higher education. London: RoutledgeFalmer.

Lim, Y-M., Teck, H. L., Ching, S. Y., \& Chui, C. L. (2016). Employability Skills, Personal Qualities, and Early Employment Problems of Entry-level Auditors: Perspectives from Employers, Lecturers, Auditors, and Students. Journal of Education for Business, 91(4), 185-192.

Ministry of Higher Education. (2019). Graduates Tracer Study. Retrieved March 15, 2019 from https://www.moe.gov.my/en/muat-turun/laporan-dan-statistik/pendidikan-tinggi/bukuperangkaan/2018-10/2408-statistik-pendidikan-tinggi-2018-bab-7-pdf/file

Patton, M. Q. (2002). Qualitative evaluation and research methods. 3rd ed. Thousand Oaks: SAGE Publications.

Perkins, D. N., \& Salomon, G. (1989). Are Cognitive Skills Context-bound?. Educational researcher, $18(1), 16-25$.

Sanghi, S. (2016). The handbook of competency mapping: understanding, designing and implementing competency models in organizations. SAGE Publications India.

Scott, G., \& Yates, K. W. (2002). Using successful Graduates to Improve the Quality of Undergraduate Engineering Programmes. European Journal of Engineering, 27, 363-378.

Singh, A., \& Pathak, V. (2016). Competency Based Management in an Organization: The Drive towards Success. IITM Journal of Business Studies (JBS), 3(1), 3-8.

Sisson, L. G., \& Adams, A. R. (2013). Essential Hospitality Management Competencies: The Importance of Soft Skills. Journal of Hospitality \& Tourism Education, 25(3), 131-145.

Tesone, D. V., \& Ricci, P. (2005). Attributes of Entry-Level Employees: Hospitality and Tourism Managers Seeking More Than Knowledge and Skills. Journal of Applied Management and Entrepreneurship, 10(2), 3-10.

Thompson, J., Stuart, R., \& Lindsay, R. P. (1997). The Competence of Top Team Members; a Framework for Successful Performance. Team Performance Management, 3, 2, 57-75.

Tongco, M. D. C. (2007). Purposive Sampling as a Aool for Informant Selection. Ethnobotany Research and Applications, 5: 147-158.

Tsai, F. C., Goh, B. K., Huffman, L., \& Wu, C. K. (2006). Competency Assessment for Entry-level Lodging Management Trainees in Taiwan. Chinese Economy, 39(6), 49-69.

Wang, Y. F., \& Tsai, C. T. (2014) Employability of Hospitality Graduates: Student and Industry Perspectives. Journal of Hospitality \& Tourism Education, 26, 125-135.

Weber, M. R., Finley, D. A., Crawford, A., \& Rivera, D. JR. (2009). An Exploratory Study ldentifying Soft Skills Competencies in Entry-Level Managers. Tourism and Hospitality Research, 9(4), 353-361.

Weinert, F. E. (2001). Concept of competence: A conceptual clarification. In D. S. Rychen and L., H. Salganik eds.., Defining and Selecting Key Competencies. Seattle: Hofgrefe \& Huber.

Zaitseva, N. A., Kozlov, D. A., \& Nikolskaya, E. Y. (2017). Evaluation of the Competencies of Graduates of Higher Educational Institutions, Engaged in the Training of Personnel for Tourism and Hospitality. Eurasian Journal of Analytical Chemistry, 12(5b), 685-695. 